\title{
EFEKTIVITAS ABU CANGKANG SAWIT DALAM MENINGKATKAN KUALITAS MINYAK GORENG CURAH DAN MINYAK GORENG KEMASAN
}

\author{
Lidya Novita*, Esthy Rahman Asih, Yuliana Arsil \\ Poltekkes Kemenkes Riau \\ *email : lidya@pkr.ac.id
}

Received 30 Oktober 2021

Accepted 9 Desember 2021

\begin{abstract}
Abstrak
Pemakaian minyak goreng berulang menyebabkan terjadinya oksidasi yang lebih tinggi pada minyak. Abu cangkang sawit dapat meningkatkan kualitas minyak jelantah karena bersifat adsorben. Tujuan penelitian ini menentukan efektivitas abu cangkang sawit dalam meningkatkan kualitas minyak jelantah dari pemakaian berulang minyak goreng curah dan kemasan ditinjau dari parameter kualitas minyak goreng sesuai Standard Nasional Indonesia (SNI). Metode dalam penelitian ini adalah menggunakan minyak curah dan kemasan dengan 4 kali pemakaian pada penggorengan ikan lele. Minyak jelantah hasil pengulangan kemudian diperlakukan dengan abu cangkang sawit pada kondisi optimum yang diperoleh pada penelitian sebelumnya yaitu perendaman $20 \mathrm{~g}$ abu cangkang sawit selama 2 minggu dalam $50 \mathrm{~mL}$ minyak jelantah. Hasil dalam penelitian ini diperoleh bahwa efektivitas abu cangkang sawit tertinggi yaitu pada pengulangan pemakaian minyak yang kedua kali (P2). Abu cangkang sawit lebih direkomendasikan untuk peningkatan kualitas minyak jelantah yang berasal dari minyak goreng kemasan (MK P2). Efektivitas abu cangkang sawit tertinggi pada MK P2 untuk parameter warna adalah sebesar 35,56\%, kadar air 40,19\%, asam lemak bebas 55,50\%, angka peroksida 40,17\%. Efektivitas abu cangkang sawit menurun dengan semakin banyaknya jumlah pemakaian minyak goreng.
\end{abstract}

Kata kunci: abu cangkang sawit, minyak jelantah, minyak curah, minyak kemasan

\begin{abstract}
Repeated use of cooking oil can lead to higher oxidation of the oil. Palm kernel shell ash (PKSA) can improve the quality of used cooking oil due to its high silica content. This study aimed to determine the effectiveness of PKSA to improve the quality of used cooking oil from bulk and packaged cooking oil according to the quality requirements for palm cooking oil in Indonesian National Standard (SNI). The method used in this research to use bulk and packaged cooking oil 4 times usage in the catfish frying. The used cooking oil was then soaked with PKSA at the optimum conditions obtained in the previous study, namely soaking $20 \mathrm{~g}$ of PKSA for 2 weeks in $50 \mathrm{~mL}$ of used cooking oil. This study showed that the highest effectiveness of PKSA was the second repetition (P2) of cooking oil. PKSA is recommended to improve the quality of used cooking oil from packaged cooking oil (MK P2). The highest effectiveness of PKSA on MK P2 for color parameter was $35.56 \%$, moisture content $40.19 \%$, free fatty acids $55.50 \%$, peroxide value $40.17 \%$. The effectiveness of PKSA decreases with the increasing use of cooking oil.
\end{abstract}

Keywords: PKSA, used cooking oil, bulk, packaged, cooking oil 


\section{Pendahuluan}

Minyak goreng digunakan dalam proses penggorengan bahan pangan untuk membuat makanan menjadi lebih garing dan lebih menarik dengan warna keemasan dan kecoklatan (Hidayati et al., 2016). Ada dua jenis minyak goreng yaitu minyak kemasan dan minyak curah. Minyak kemasan cenderung memiliki warna yang lebih cerah serta lebih jernih, sedangkan minyak curah berwarna lebih keruh (Lempang et al., 2016). Minyak goreng curah memiliki kadar asam lemak bebas lebih tinggi yaitu $0,16 \%$ dibandingkan minyak goreng kemasan yaitu $0,12 \%$ tanpa adanya perlakuan pemanasan (Mahmudah et al., 2019). Pemanasan yang tinggi selama proses penggorengan (200$250^{\circ} \mathrm{C}$ ), membuat terjadinya kerusakan pada minyak serta akan mempengaruhi nilai gizi pangan (Rahayu et al., 2014). Dekomposisi trigliserida dalam minyak goreng dipengaruhi oleh suhu pemanasan serta kandungan bahan pangan yang digoreng (Hasibuan, 2014). Menggoreng bahan pangan pada minyak yang sama berulang kali akan memicu terjadinya oksidasi yang mengakibatkan meningkatnya bilangan peroksida pada minyak (Rahayu et al., 2014). Penggunaan minyak jelantah secara terus menerus pada manusia dapat memicu timbulnya berbagai penyakit, salah satunya adalah menumpuknya lemak pada dinding pembuluh darah, penyakit kanker serta dapat mengurangi kecerdasan generasi berikutnya (Novita et al., 2020). Asam lemak akan mudah terhidrolisis jika dominan memiliki ikatan tunggal. Proses oksidasi dan hidrolisis pada minyak dapat menurunkan kualitas minyak (Suroso, 2013).

Penelitian oleh Zarina et al. (2013) mengenai karakterisasi abu cangkang sawit, diperoleh kadar $\mathrm{SiO}_{2} 51,18 \%, \mathrm{Al}_{2} \mathrm{O}_{3}$ $4,61 \%, \mathrm{Fe}_{2} \mathrm{O}_{3} 3,42 \%, \mathrm{CaO} 6,93 \%$ dan $\mathrm{MgO} 4,02 \%$ sehingga sangat efektif untuk pemakaian abu cangkang sawit sebagai adsorben.
Cangkang atau tempurung kelapa sawit mencapai $60 \%$ dari keseluruhan limbah produksi minyak sawit. Arang aktif merupakan hasil pembakaran cangkang sawit. Arang aktif sangat luas penggunaannya di berbagai bidang, antara lain farmasi dan filtrasi pada industri karet dan gula. Arang aktif adalah padatan berpori yang terikat secara kovalen sehingga membuat permukaannya bersifat nonpolar. Semakin kecil ukuran pori, membuat luas permukaannya arang semakin besar. Hal ini membuat kecepatan adsorpsi bertambah (Meisrilestari et al., 2013).

Edmund et al. (2014) melakukan karakterisasi abu cangkang sawit untuk kegunaannya sebagai adsorben pada penjernihan air. Hasil karakterisasi dengan fotoelektron sinar-X pada penelitian ini menunjukkan kandungan karbon yang tinggi pada permukaan lapisan abu sebesar 49,79\%, hasil karakterisasi dengan alat SEM menunjukkan ukuran pori yang besar yaitu $51,8 \times 30,56 \mu \mathrm{m}$ sehingga membuat abu cangkang sawit sangat efektif dijadikan bahan adsorben.

Beberapa penelitian tentang minyak jelantah memperlihatkan bahwa kualitas minyak yang dipakai berulang akan menurun, khususnya pada bilangan peroksida serta bilangan asam. Baku mutu yang dipakai di Indonesia untuk minyak goreng adalah nilai pada SNI (BSN, 2019), warna minyak goreng mulai dari kuning muda sampai kuning, kandungan air maksimum $0,30 \%$, asam lemak bebas maksimum $0,3 \%$, bilangan peroksida 1,00 $\mathrm{mgO}_{2} / 100 \mathrm{~g}$.

Yustinah et al. (2011) meneliti tentang adsorbsi minyak jelantah menggunakan arang dari sabut kelapa, pada penelitian ini digunakan variasi berat arang 2, 4, 6, 8, 10 dan 12 g untuk setiap $200 \mathrm{~mL}$ minyak. Hasil yang diperoleh terjadi penurunan angka peroksida sebesar 10,88 meq $\mathrm{H}_{2} \mathrm{O}_{2} / \mathrm{Kg}$ pada pemakaian $10 \mathrm{~g}$ arang, dan penurunan absorbansi warna minyak jelantah pada pemakaian $12 \mathrm{~g}$ arang. 
Zein et al. (2016) menggunakan abu sekam padi untuk meningkatkan kualitas minyak jelantah, pada penelitian ini ditentukan berat optimum abu sekam padi dengan variasi 5, 10, 15 dan $20 \mathrm{~g}$ dengan perendaman dalam $50 \mathrm{~mL}$ minyak jelantah selama dua minggu. Berat optimum yang diperoleh, digunakan untuk menentukan waktu kontak optimum perendaman abu sekam padi dengan variasi 1, 2, 3 dan 4 minggu. Berat optimum yang diperoleh adalah sebanyak $20 \mathrm{~g}$ abu sekam padi dan waktu kontak optimum dengan pemakaian $20 \mathrm{~g}$ abu sekam padi adalah 4 minggu. Pemakaian abu sekam padi untuk menjernihkan minyak jelantah dapat menurunkan kadar asam lemak bebas hingga mencapai $74,42 \%$, angka peroksida $69,22 \%$, kolesterol $17,09 \%$, trigliserida 46,63\%, LDL 33,24\% dan MDA 24,02\%. Warna dari minyak jelantah dalam penelitian tersebut yang diuji secara spektrofotometri meningkat kejernihannya hingga mencapai $69,80 \%$.

Penelitian terdahulu oleh Novita et al. (2020) menentukan berat optimum dan waktu kontak optimum abu cangkang sawit dalam meningkatkan kualitas minyak jelantah sesuai parameter syarat mutu minyak goreng (BSN, 2019). Kondisi optimum yang diperoleh adalah berat abu cangkang sawit $20 \mathrm{~g}$ abu dalam $50 \mathrm{~mL}$ minyak dengan waktu kontak 2 minggu. Penelitian ini menggunakan kondisi optimum tersebut untuk meningkatkan kualitas minyak jelantah dari penggorengan ikan lele pada minyak kemasan dan minyak curah dengan variasi penggorengan berulang. Tujuan penelitian ini menentukan efektivitas abu cangkang sawit dalam meningkatkan kualitas minyak jelantah dari pemakaian berulang minyak goreng curah dan kemasan ditinjau dari parameter kualitas minyak goreng sesuai Standard Nasional Indonesia (SNI).

\section{Metode Penelitian Bahan}

Bahan pada penelitian ini adalah minyak curah dari pasar tradisional di
Pekanbaru, minyak kemasan diperoleh dari supermarket di Pekanbaru. Abu kelapa sawit diperoleh dari pabrik pengolahan minyak kelapa sawit di Kabupaten Siak, Riau.

\section{Tahapan penelitian}

Penelitian ini terbagi dalam tiga tahap. Tahap pertama, minyak curah dan minyak kemasan digunakan untuk menggoreng ikan lele, dilakukan pengulangan sebanyak 4 kali untuk masing-masing minyak goreng sebagai berikut: minyak kemasan pada pengulangan kedua (MK P2), minyak curah pengulangan kedua (MC P2), minyak kemasan pengulangan ketiga (MK P3), minyak curah pengulangan ketiga (MC P3), minyak kemasan pengulangan keempat (MK P4), minyak curah pengulangan keempat (MC P4).

Tahap kedua, minyak jelantah dari pengulangan penggorengan selanjutnya di rendam dengan abu cangkang sawit dengan kondisi optimum $20 \mathrm{~g}$ abu dalam $50 \mathrm{~mL}$ minyak selama 2 minggu. Tahap ketiga, dilakukan analisis parameter minyak sesuai SNI (BSN, 2019) yaitu analisis warna, kadar air, angka peroksida dan asam lemak bebas.

Pemakaian berulang minyak curah dan minyak kemasan (Anwariah et al., 2018)

Jumlah ikan lele yang dipakai untuk setiap kali penggorengan adalah $500 \mathrm{~g}$. Jumlah minyak yang digunakan adalah 3 L. Suhu setiap kali proses penggorengan adalah $180^{\circ} \mathrm{C}$ dengan lama penggorengan 10 menit.

Minyak jelantah dari penggorengan berulang kemudian diperlakukan dengan abu cangkang sawit dengan proses perendaman. Pemakaian abu sebanyak 20 g setiap $50 \mathrm{~mL}$ minyak jelantah, dengan perendaman selama 2 minggu. Proses selanjutnya dilakukan penyaringan dan analisis berbagai parameter kualitas minyak jelantah. Proses ini bertujuan untuk menentukan efektivitas abu cangkang sawit dalam meningkatkan kualitas minyak jelantah dari 
penggorengan berulang minyak goreng curah dan minyak goreng kemasan.

\section{Analisis warna (AOCS, 2009)}

Sampel dituangkan ke dalam kuvet berukuran $25,4 \mathrm{~mm}$ yang kering dan bersih. Lalu kuvet diletakkan ke dalam kabin pada alat kolorimeter (Lovibond, Inggris), setelah itu dilakukan penentuan warna menggunakan standar warna yang terdapat pada alat kolorimeter dengan perbandingan nilai merah dan kuning adalah 1:10.
Kadar air (AOCS, 2009)

Sampel dilelehkan serta dihomogenkan sebelum ditimbang, tetapi jangan dipanaskan lebih dari $10^{\circ} \mathrm{C}$ melebihi titik leleh contoh. Ditimbang dengan teliti $5 \mathrm{~g}$ sampel kedalam wadah timbangan (Pyrex, Jerman) yang telah dikeringkan kemudian didinginkan di dalam desikator, dimasukkan ke dalam oven (Memmert UF 55, Jerman) pada suhu $130^{\circ} \mathrm{C}$ selama 30 menit, lalu dimasukkan ke desikator dan ditimbang.

$$
\text { Kadar air }=\frac{(\text { berat botol }+ \text { sampel basah })-(\text { berat botol+sampel kering })}{\text { berat sampel }(\mathrm{g})}
$$

Angka peroksida (AOCS, 2009)

Sampel ditimbang sebanyak $5 \mathrm{~g}$, ditambahkan $50 \mathrm{~mL}$ campuran asam asetat (3): isooktana (2) (Merck), diaduk sampai larut, ditambahkan $0,5 \mathrm{~mL}$ larutan $\mathrm{KI}$ jenuh, didiamkan selama 1 menit, kemudian larutan diaduk sebanyak 3 kali dan ditambahkan $30 \mathrm{~mL}$ aquades, dititrasi dengan natrium tiosulfat (Merck) $0,1 \mathrm{M}$, sampai warna kuning iodin hilang, ditambahkan indikator amilum, dilanjutkan titrasi sampai warna biru hilang, lakukan juga terhadap blanko.

$$
\text { Angka peroksida }=\frac{((\mathrm{S}-\mathrm{B}) \times \mathrm{N} \times 1000)}{\text { berat sampel }(\mathrm{g})} \ldots \ldots
$$

Keterangan

$\mathrm{S}=$ Volume titrasi Sampel

$\mathrm{B}=$ Volume titrasi Blanko

\section{Asam lemak bebas (AOCS, 2009)}

Sampel ditimbang sebanyak 28,2 g lalu dihomogenkan, ditambahkan $50 \mathrm{~mL}$ alkohol, dipanaskan sampai tepat didih, dilanjutkan dengan proses titrasi menggunakan $\mathrm{NaOH}$ (Merck) $0,1 \mathrm{~N}$ sampai terbentuk warna merah muda menggunakan indikator pp (Merck).

$$
\mathrm{ALB}=\frac{\mathrm{ml} \mathrm{NaOH} \times \mathrm{N} \mathrm{NaOH} \times 25,6}{\text { berat sampel }(\mathrm{g})}
$$

Keterangan

ALB $=$ Asam Lemak Bebas
Perhitungan efektivitas abu cangkang sawit

Efektivitas abu cangkang sawit dalam meningkatkan kualitas minyak jelantah dihitung dengan rumus berikut ini :

$$
\text { Efektivitas }(\%)=\frac{\mathrm{A}-\mathrm{B}}{\mathrm{A}} \times 100
$$

Keterangan

$\mathrm{A}=$ Nilai parameter minyak jelantah sebelum perlakuan dengan abu cangkang sawit

$\mathrm{B}=$ Nilai parameter minyak jelantah sesudah perlakuan dengan abu cangkang sawit

\section{Hasil dan Pembahasan}

Keefektivan abu cangkang sawit terhadap parameter warna

Keefektivan abu cangkang sawit terhadap parameter warna dapat dilihat pada Gambar 1.

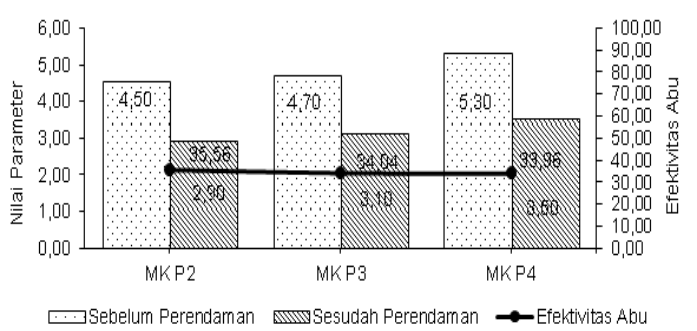


B

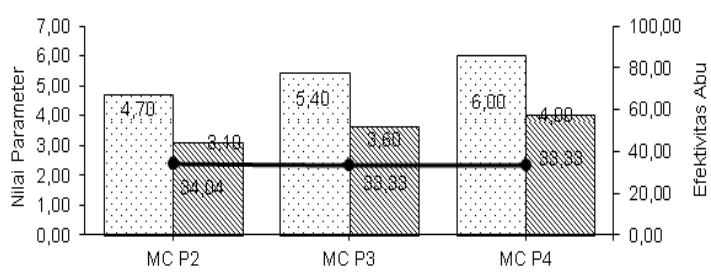

$\multimap$ Sebelum Perendarnan

Gambar 1. Diagram nilai efektivitas abu cangkang sawit dalam meningkatkan kualitas warna minyak jelantah dari (A) minyak goreng kemasan, (B) minyak goreng curah

Syarat mutu minyak goreng sesuai SNI (BSN, 2019) untuk warna adalah dari putih kuning pucat sampai kuning yang berarti semakin rendahnya intensitas warna kuning kecoklatan pada minyak jelantah maka semakin baik kualitas minyak jelantah dari segi warna. Gambar 1 menunjukkan bahwa semakin sering minyak dipakai untuk menggoreng maka intensitas warna minyak jelantah menjadi kuning kecoklatan juga semakin tinggi baik pada minyak goreng kemasan maupun curah. Efektivitas abu cangkang sawit dalam meningkatkan kualitas warna dari minyak jelantah sesudah perendaman selama 2 minggu adalah 35,56\% pada penggorengan ke 2 menurun sedikit menjadi 33,96\% pada penggorengan ke 4 untuk minyak goreng kemasan. Pada minyak goreng curah, efektivitas abu cangkang sawit juga berkisar pada angka $30 \%$ yaitu $34,04 \%$ pada penggorengan ke 2 dan menurun menjadi $33,33 \%$ pada penggorengan ke 4 .

Abu cangkang sawit mengandung karbon yang cukup tinggi yaitu 49,79\%. Karbon dapat mengabsorpsi komponen pengotor yang terdapat dalam minyak jelantah, sehingga warna kuning kecoklatan pada minyak dapat berkurang menjadi warna kuning yang lebih jernih (Aritonang et al., 2018). Semakin sering minyak goreng dipakai menyebabkan semakin tinggi jumlah komponen pengotor pada minyak jelantah, sehingga efektivitas karbon dalam abu cangkang sawit juga semakin menurun dalam menyerap komponen pengotor minyak jelantah. Secara umum efektivitas abu cangkang sawit dalam meningkatkan kualitas warna minyak jelantah baik dari minyak goreng kemasan maupun minyak goreng curah berkisar pada angka 33,33 hingga 35,56\%.

Penelitian Aritonang et al. (2018) menggunakan karbon aktif dari cangkang kemiri untuk melihat penurunan angka peroksida sekaligus melihat tingkat kejernihan minyak jelantah. Karbon yang terkandung di dalam cangkang kemiri juga mampu menyerap kandungan pengotor dalam minyak jelantah, namun studi ini tidak menghitung efektivitas karbon cangkang kemiri dalam meningkatkan kejernihan minyak jelantah.

Keefektivan abu cangkang sawit terhadap parameter kadar air

Keefektivan abu cangkang sawit terhadap parameter kadar air dapat dilihat pada gambar 2 dibawah ini :

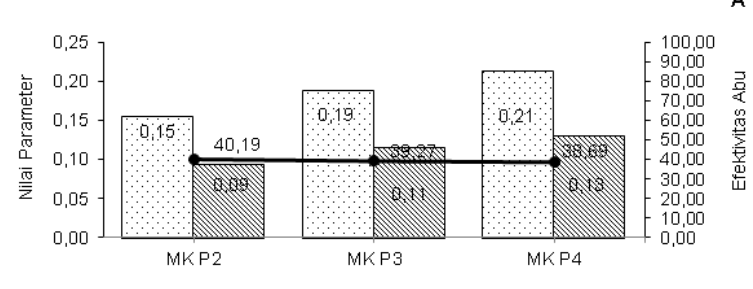

$\cdots$ Sebelum Perendaman $\mathrm{am}$ Sesudah Perendaman $\rightarrow$-Efektivitas Abu

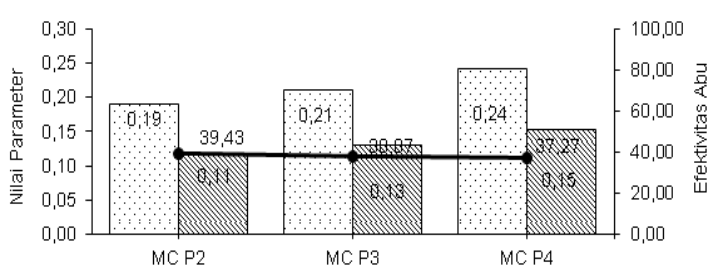

$\rightarrow$ Sebelum Perendaman

Gambar 2. Diagram nilai efektivitas abu cangkang sawit dalam meningkatkan kualitas kadar air minyak jelantah dari (A) minyak goreng kemasan, (B) minyak goreng curah 
Gambar 2 memperlihatkan diagram perbandingan parameter kadar air sebelum dan sesudah perendaman dengan abu cangkang sawit pada berbagai variasi penggorengan serta efektivitas abu cangkang sawit dalam meningkatkan kualitas kadar air minyak jelantah dari (A) minyak kemasan dan (B) minyak curah.

Efektivitas abu cangkang sawit dalam meningkatkan kualitas kadar air dari minyak jelantah sesudah perendaman selama 2 minggu adalah 40,19\% pada penggorengan ke 2 menurun menjadi $38,69 \%$ pada penggorengan ke 4 untuk minyak goreng kemasan. Pada minyak goreng curah, efektivitas abu cangkang sawit sebesar $39,43 \%$ pada penggorengan ke 2 dan menurun menjadi 37,27\% pada penggorengan ke 4 . Kandungan silika dalam abu cangkang sawit dapat berperan sebagai adsorben yang dapat mengikat air sehingga gugus siloksan berubah menjadi gugus silanol. Semakin sering minyak dipakai maka kandungan air dalam minyak juga semakin besar, sehingga membuat gugus siloksan abu cangkang sawit juga menjadi cepat jenuh menjadi gugus silanol menyebabkan efektivitas abu cangkang sawit menjadi menurun.

Bau tengik pada minyak dapat terjadi akibat adanya asam lemak bebas dari reaksi hidrolisis minyak. Keberadaan asam, basa dan enzim yang bersumber dari bahan yang digoreng, dapat mempercepat reaksi hidrolisis pada minyak. Mikroorganisme dalam minyak dapat tumbuh melalui media air yang terkandung dalam minyak. Adanya air dalam minyak secara keseluruhan dapat menurunkan kualitas minyak (Hatta et al., 2013).

\section{Keefektivan abu cangkang sawit terhadap parameter asam lemak bebas}

Keefektivan abu cangkang sawit terhadap parameter asam lemak bebas dapat dilihat pada Gambar 3.

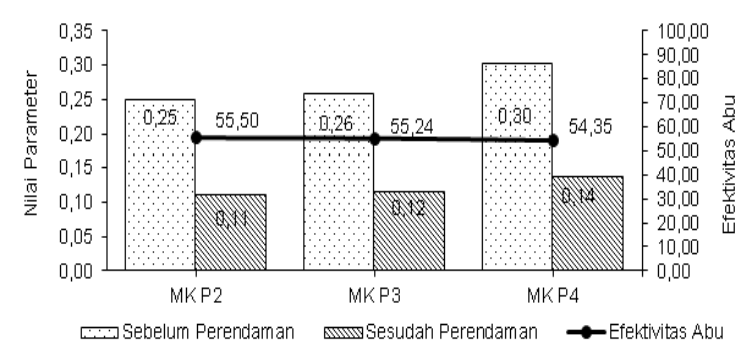

B

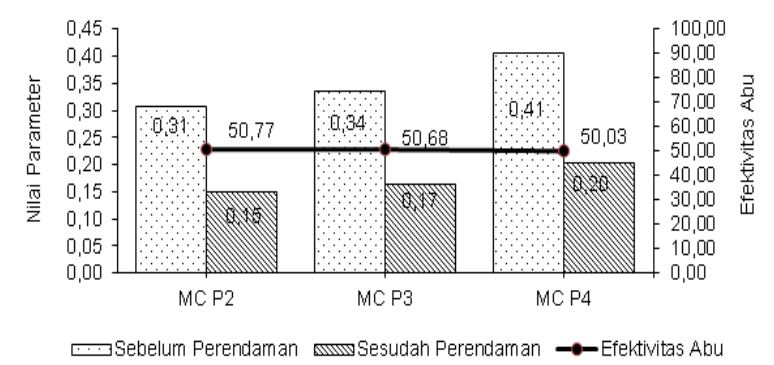

Gambar 3. Diagram nilai efektivitas abu cangkang sawit dalam meningkatkan kualitas asam lemak bebas minyak jelantah dari (A) minyak goreng kemasan, (B) minyak goreng curah

Gambar 3 menunjukkan diagram perbandingan nilai parameter asam lemak bebas sebelum dan sesudah perendaman dengan abu cangkang sawit pada berbagai variasi penggorengan serta efektivitas abu cangkang sawit.

Efektivitas abu cangkang sawit dalam meningkatkan kualitas asam lemak bebas dari minyak jelantah sesudah perendaman selama 2 minggu adalah $55,50 \%$ pada penggorengan ke 2 menurun menjadi $54,35 \%$ pada penggorengan ke 4 untuk minyak goreng kemasan. Pada minyak goreng curah, efektivitas abu cangkang sawit sebesar $50,77 \%$ pada penggorengan ke 2 dan menurun menjadi $50,03 \%$ pada penggorengan ke 4 . Oksigen pada gugus karbonil asam lemak dapat terikat pada permukaan silika abu cangkang sawit melalui gugus silanol. Ikatan yang terjadi adalah ikatan hidrogen antara atom oksigen pada gugus karbonil asam lemak dengan atom hidrogen pada gugus silanol (Yang, 2003). Tingginya konsentrasi asam 
lemak yang bebas dalam minyak jelantah menyebabkan semakin cepat terjadi kejenuhan pada permukaan silika abu cangkang sawit yang berakibat turunnya efektivitas abu dalam menurunkan parameter asam lemak bebas minyak jelantah.

Reaksi hidrolisis menyebabkan terbentuknya asam lemak bebas pada minyak. Reaksi hidrolisis dipicu oleh adanya air pada pangan yang digoreng, dipercepat oleh pemanasan, keasaman dan katalis. Hasil hidrolisis minyak sawit adalah gliserol serta asam lemak bebas. Banyaknya asam lemak bebas dalam minyak menyebabkan rendemen minyak sebagai trigliserida menjadi turun (Mardina et al., 2012).

\section{Keefektivan abu cangkang sawit terhadap parameter angka peroksida}

Keefektivan abu cangkang sawit terhadap parameter angka peroksida dapat dilihat pada Gambar 4.
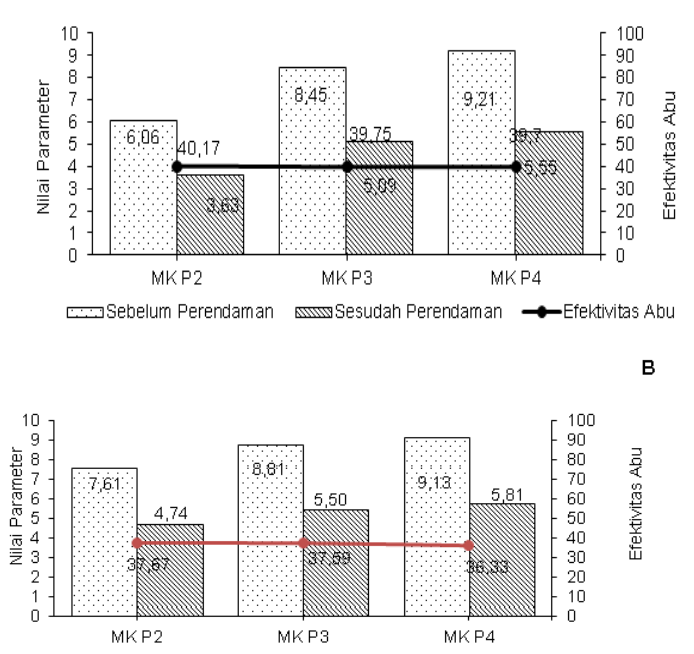

$\longrightarrow$ Sebelum Perendarnan

Gambar 4. Diagram nilai efektivitas abu cangkang sawit dalam meningkatkan kualitas angka peroksida minyak jelantah dari minyak goreng kemasan

Gambar 4 menunjukkan diagram perbandingan nilai parameter angka peroksida sebelum dan sesudah perendaman dengan abu cangkang sawit pada berbagai variasi penggorengan serta efektivitas abu cangkang sawit dalam meningkatkan kualitas angka peroksida minyak jelantah dari (A) minyak kemasan dan (B) minyak curah.

Efektivitas abu cangkang sawit dalam meningkatkan kualitas angka peroksida dari minyak jelantah sesudah perendaman selama 2 minggu adalah $40,17 \%$ pada penggorengan ke 2 menurun menjadi $39,70 \%$ pada penggorengan ke 4 untuk minyak goreng kemasan. Pada minyak goreng curah, efektivitas abu cangkang sawit sebesar $37,67 \%$ pada penggorengan ke 2 dan menurun menjadi $36,33 \%$ pada penggorengan ke 4 .

Angka peroksida merupakan jumlah mol equivalen oksigen yang terkandung dalam $1 \mathrm{Kg}$ minyak atau lemak. Angka ini mengindikasikan level turunnya kualitas minyak karena proses oksidasi. Asam lemak yang tidak jenuh merupakan konstituen trigliserida yang dapat bereaksi dengan oksigen pada ikatan rangkap yang terkandung didalamnya, yang dapat membentuk peroksida (Hajar et al., 2016). Perendaman abu cangkang sawit pada minyak jelantah akan menyerap peroksida dalam tiga tahapan. Tahap awal peroksida terserap pada permukaan karbon yang terkandung dalam abu cangkang sawit. Tahap selanjutnya, peroksida bergerak menuju pori-pori karbon lalu terserap ke bagian dalam karbon (Aritonang et al., 2018).

Semakin tinggi kandungan peroksida dalam minyak jelantah mengakibatkan kandungan karbon dalam abu cangkang sawit juga menjadi jenuh dengan peroksida yang terperangkap didalamnya sehingga menurunkan efektivitas abu dalam menurunkan parameter angka peroksida dengan semakin banyaknya pengulangan pemakaian minyak goreng. Secara umum nilai efektivitas abu cangkang sawit pada minyak jelantah dari minyak goreng curah lebih rendah. Hal ini berarti minyak goreng curah memiliki kandungan peroksida yang lebih tinggi bahkan sebelum dipakai karena kemungkinan terpapar oksigen dari 
udara yang juga lebih tinggi saat masih berada ditangan produsen.

Penelitian Aritonang et al., (2018) menggunakan karbon aktif dari cangkang kemiri untuk mendegradasi angka peroksida minyak jelantah. Kadar peroksida sampel minyak goreng sesudah 6 kali penggorengan sebelum pemberian arang aktif sebesar 9,3762 meq O2/kg, setelah dilakukan pemurnian dengan menggunakan adsorben dari arang aktif cangkang kemiri kadar bilangan peroksida menurun menjadi 7,3428 meq $\mathrm{O} 2 / \mathrm{kg}$. Penurunan angka peroksida ini juga belum memenuhi ketentuan syarat mutu minyak goreng dalam SNI (BSN, 2019) bahwa kadar maksimum peroksida minyak goreng adalah $1 \mathrm{meq} / \mathrm{Kg}$.

\section{Kesimpulan}

Efektivitas abu cangkang sawit tertinggi yaitu pada pengulangan pemakaian minyak yang kedua kali (P2). Abu cangkang sawit lebih direkomendasikan untuk peningkatan kualitas minyak jelantah yang berasal dari

\section{Daftar Pustaka}

Anwariah R, Lastrianto A, Sumarlan SH., 2018. Efek penggorengan berulang menggunakan vacuum frying terhadap kualitas fisik dan kimia minyak goreng pada penggorengan ikan lele (Clarias Gariepinus B.). J Keteknikan Pertanian Tropis dan Biosistem 6(2): 172-178.

[AOCS] Association of Official Analytical Chemists., 2009. Official Methods and Recommended Practice of The AOCS. 6th edn. USA.

Aritonang B, Hestina., 2018. Daya adsorpsi karbon aktif dari cangkang kemiri terhadap kadar bilangan peroksida pada minyak goreng bekas. J Kimia Saintek dan Pendidikan II(1): 21-30.

[BSN] Badan Standardisasi Nasional., 2019. Standar Nasional Indonesia (SNI) Minyak Goreng 7709-2019. Badan Standardisasi Nasional, minyak goreng kemasan (MK P2). Berdasarkan standar mutu minyak goreng sawit menurut SNI 7709-2019, nilai parameter warna minyak jelantah pada MK P2 menurun dari 4,5 (kuning kecoklatan) menjadi 2,9 (kuning) dengan efektivitas abu cangkang sawit sebesar $35,56 \%$. Nilai parameter kadar air pada MK P2 menurun dari $0,15 \%$ menjadi $0,09 \%$ dengan efektivitas abu cangkang sawit sebesar $40,19 \%$. Nilai parameter asam lemak bebas pada MK P2 menurun dari $0,25 \%$ menjadi $0,11 \%$ dengan efektivitas abu cangkang sawit sebesar $55,50 \%$. Nilai parameter angka peroksida menurun dari $6,06 \mathrm{mg}$ eq $/ \mathrm{Kg}$ menjadi 3,63 $\mathrm{mg}$ eq/Kg dengan efektivitas abu cangkang sawit sebesar $40,17 \%$.

\section{Saran}

Penelitian ini dapat dilanjutkan dengan melihat pengaruh proses pengadukan pada proses perendaman abu cangkang sawit dengan minyak jelantah terhadap efektivitas abu cangkang sawit dalam meningkatkan kualitas minyak jelantah.

\section{Jakarta.}

Edmund CO, Christopher MS, Pascal DK., 2014. Characterization of palm kernel shell for materials reinforcement and water treatment. J Chemical Engineering and Materials Science 5(1): 1-6.

Hajar EWI, Auxilia FWP, Putri H, Mardiah., 2016. Proses pemurnian minyak jelantah menggunakan ampas tebu untuk pembuatan sabun padat. $\mathbf{J}$ Integrasi Proses 6(2): 57-63.

Hasibuan R., 2014. Peningkatan angka peroksida pada minyak goreng curah terhadap penggorengan berulang tempe. J Ilmiah Pannmed 8(3): 258262.

Hatta DM, Siregar HP, Yusra M., 2013. Penggunaan karbon aktif dari biji kelor dapat memurnikan minyak jelantah. J Teknik Kimia 19(3): 4453.

Hidayati FC, Masturi, Yulianti I., 2016. 
Pemurnian minyak goreng bekas pakai (jelantah) dengan menggunakan arang bonggol jagung. JIPF (Jurnal Ilmu Pendidikan Fisika) 1(2): 67-70.

Lempang IR, Fatimawali, Pelelalu NC., 2016. Uji kualitas minyak goreng curah dan minyak goreng kemasan di Manado. J Ilmiah Farmasi 5(4): 155161.

Mahmudah K, Vivin N., 2019. Penetapan kadar asam lemak (ALB) pada minyak goreng kemasan dan minyak goreng curah dengan perlakuan berdasarkan lama waktu pemanasan. J Ilmu Farmasi 10(1): 1-4.

Mardina P, Faradina E, Setiawati N., 2012. Penurunan angka asam pada minyak jelantah. J Kimia 6(2): 196-200.

Meisrilestari YR, Khomaini H, Wijayanti., 2013. Pembuatan arang aktif dari cangkang kelapa sawit dengan aktivasi secara fisika, kimia dan fisika-kimia. J Konversi 2(1): 46-51.

Mulyati TA, Pujiono FE, Lukis PA., 2015. Pengaruh lama pemanasan terhadap kualitas minyak goreng kemasan kelapa sawit. J Wiyata 2(2): 162-168.

Novita L, Asih ER, Arsil Y., 2020. Utilization of palm kernel shell ash to improve used palm cooking oil quality. Proceedings $4^{\text {th }}$ International Symposium on Health Research (ISHR 2019). 255-260.

Rahayu LH, Purnavita S., 2014. Pengaruh suhu dan waktu adsorpsi terhadap sifat kimia-fisika minyak goreng bekas hasil pemurnian menggunakan adsorben ampas pati aren dan bentonit. J Momentum UNWAHAS
10(2): 35-41.

Rahayu LH, Purnavita S, Sriyana HY., 2014. Potensi sabut dan tempurung kelapa sebagai adsorben untuk meregenerasi minyak jelantah. J Momentum UNWAHAS 10(1): 4753.

Siswanto W, Mulasari SA., 2015. Pengaruh frekuensi penggorengan terhadap peningkatan peroksida minyak goreng curah dan fortifikasi vitamin A. J Kesehatan Masyarakat (Journal of Public Health) 9(1): 1-10.

Suroso AS., 2013. Kualitas minyak goreng habis pakai ditinjau dari bilangan peroksida, bilangan asam dan kadar air. J Kefarmasian Indonesia 3(2): 7788.

Yang RT., 2003. Adsorbent: Fundamentals and Application. John Wiley \& Sons Inc, New Jersey, 117119.

Yustinah, Hartini., 2011. Adsorbsi minyak goreng bekas menggunakan arang aktif dari sabut kelapa. Prosiding Seminar Nasional Teknik Kimia Kejuangan. B05-1-B05-5.

Zarina Y, Al Bakri AMM, Kamarudin H, Nizar IK, Rafiza AR., 2013. Review on the various ash from palm oil waste as geopolymer material. Reviews on Advanced Materials Science 34(1): 37-43.

Zein R, Silfia NA, Ermi G, Hermansyah A., 2016. Improvement in quality of used palm oil by rice husk ash. Research Journal of Pharmaceutical, Biological and Chemical Science 2: 121-130. 